\title{
Red cell deformability is not an independent risk factor in stroke
}

\author{
SS POLLOCK, MJG HARRISON
}

From the Department of Neurological Studies, Middlesex Hospital Medical School, London

SUMMARY Reduced erythrocyte deformability has been implicated in the causation of stroke. We have therefore tested this red cell property by filtration through polycarbonate membranes in 42 patients with either transient ischaemic attacks or completed ischaemic stroke together with age and sex paired controls. We have failed to demonstrate any difference between patients and controls suggesting that reduced red cell deformability is unlikely to be an important independent factor in the production of stroke.

Erythrocytes possess the ability to traverse capillaries less than half their diameter and this property of deformability also affects whole blood viscosity, particularly at high shear rates. ${ }^{1}$ Decreased filterability of erythrocytes has been reported in chronic peripheral arterial disease ${ }^{2}$ and following myocardial infarction. ${ }^{3}$ We have therefore examined red cell deformability in patients with completed ischaemic strokes and transient ischaemic attacks to determine whether it constitutes a risk factor in cerebrovascular disease.

\section{Methods}

Venous blood, anticoagulated in $3.8 \%$ sodium citrate, was taken from 16 patients with a history of transient ischaemic attacks (age range 40-78 yrs, mean $58 \pm 9.6$ yrs). Similar samples were taken from 26 patients with an ischaemic stroke occurring more than 3 months previously (age range 50-92 yrs, mean 75.6 $\pm 10 \mathrm{yrs}$ ). In addition 42 age and sex matched controls with nonvascular neurological disease were studied. Subjects with raised blood pressure or on anti-hypertensive medication or in whom there was a possible source of cardiac embolism were excluded. We also omitted patients with raised levels of blood sugar, serum blood lipids and erythrocyte sedimentation rates. No subject was taking medication known to affect red cell deformability. Smoking habits were noted in all cases.

Address for reprint requests: Dr SS Pollock, Department of Neurological Studies, Middlesex Hospital Medical School, London W1N 8AA, UK.

Received 7 November 1981

Accepted 9 December 1981
Erythrocyte deformability was measured within 2 hours of venepuncture by filtration through $5 \mu \mathrm{m}$ polycarbonate membranes (Nuclepore Corporation, Plesanton, California, USA). Whole blood was spun at $3000 \mathrm{rpm}$ for 15 minutes and the buffy coat removed. A $5 \%$ suspension of red blood cells was made in either isotonic saline or native plasma previously filtered through $2 \mu \mathrm{m}$ pore membrane. The filtrates were collected after 60 seconds and in parallel with a $1 \mathrm{ml}$ standard solution diluted to $5 \mathrm{ml}$ with Drabkin's reagent (Sigma Chemicals 525-2). Following centrifugation at $1500 \mathrm{rpm}$ for 10 minutes to remove the lysed cells, the optical density of free haemoglobin was measured at $540 \mathrm{~nm}$ (Cecil spectrophotometer CE 303 Cambridge). The deformability index was derived by dividing the optical density of the mean of three filtrates by that of the $100 \%$ lysed standard, the result being expressed as a percentage. Haematocrit levels were measured on a Hawksley microhaematocrit centrifuge.

\section{Results}

The mean percentage deformability of red blood cells in saline and plasma did not differ between patients and controls (table). Patients who smoked had less deformable cells than those who did not, an effect more noticeable in saline (patients smoking $63.7 \% \pm 11.8 \%$, patients not smoking $71.7 \% \pm$ $11.0 \% \mathrm{p}<0.05$ ) than in plasma (patients smoking $48 \% \pm 9 \%$, patients not smoking $48 \cdot 8 \% \pm 10 \cdot 8 \%$ NS). Haematocrit values were $35-50 \%$ mean $44.7 \% \pm 3.55 \%$ for completed strokes (controls $33-47 \% 41.0 \% \pm 3.7 \% \mathrm{p}<0.01$ Student's paired $t$ test) and $43.9 \% \pm 4.32 \%$ for transient ischaemic attack patients (controls $43 \cdot 2 \% \pm 2 \cdot 89 \%$ NS). 
Table Mean percentage erythrocyte deformability

\begin{tabular}{lllll}
\hline & $\begin{array}{l}\text { Ischaemic } \\
\text { stroke }\end{array}$ & Control & $\begin{array}{l}\text { Transient } \\
\text { ischaemic } \\
\text { attack }\end{array}$ & Control \\
& 26 & 26 & 16 & 16 \\
\hline Plasma & $51 \pm 11$ & $51 \pm 10 \mathrm{~ns}$ & $50 \pm 12$ & $47 \pm 11 \mathrm{~ns}$ \\
Saline & $70 \pm 9$ & $73 \pm 10 \mathrm{~ns}$ & $70 \pm 14$ & $72 \pm 9 \mathrm{~ns}$ \\
\hline
\end{tabular}

\section{Discussion}

The flexibility of erythrocytes not only permits passage through capillaries smaller than the resting cell diameter but improves circulation through larger arteries by minimising viscous energy loss and facilitating flow at arterial bifurcations. This deformability is the product of cell membrane flexibility and the ability to maintain a high surface to volume ratio, the internal viscosity of the haemoglobin and the constituents of the surrounding plasma, notably fibrinogen. It is reduced in the presence of acidosis or hypoxia ${ }^{4}$ owing to the effect on the cell membrane though this effect in vitro does not occur significantly within two hours of venesection. ${ }^{5}$ Furthermore in the presence of abnormal haemoglobin, for example in sickle cell disease, this reduction is increased and may lead to vaso-occlusive events ${ }^{6}$ including cerebral thrombosis.

Filtration through polycarbonate membranes is one of several methods of assessing red cell deformability currently in vogue. Removal of the buffy coat and dilution of the red cells overcomes the difficulty of obstruction of the membrane pores by the less deformable white cells and platelet aggregates though the suspension is not physiological. Suspension of washed red cells in isotonic saline removes the effects of plasma and tests only the intrinsic properties of the cell. Though filtration under gravity entails a variable hydrostatic pressure change dependent on the rate of filtration, this effect is small and the technique avoids the use of unphysiologically high shear stresses.

There have been several reports of reduced erythrocyte deformability as measured by microfiltration methods in cerebrovascular disease. Guerrini et al have described a reduction immediately following stroke with a subsequent improvement of 10 days. ${ }^{7}$ A similar finding has been reported following myocardial infarction. ${ }^{8}$ A number of authors $^{9-13}$ have described reduced filterability in patients with established cerebrovascular accidents but in no series were individual controls matched for age and sex; despite the fact that increasing age is known to be associated with a decline in red cell deformability. ${ }^{14}$ Patients with hypertension were not omitted so haemorrhagic strokes may have been included. Furthermore the influence of diabetes, ${ }^{15}$ raised erythrocyte sedimentation rates, and smoking habits $^{1617}$ all factors influencing red cell deformability, was not taken into account. Our failure, after allowing for these complicating factors, to demonstrate a reduction in the red cell deformability in patients with ischaemic strokes, suggests that the acute changes described by others may follow the development of a cerebral thrombosis. As such the reduction in red cell deformability might be of pathological significance impairing collateral perfusion and thereby influencing infarct size but would not constitute a risk factor.

The similarity of red cell deformability in controls and patients with a transient ischaemic attack, a known antecedent of stroke, also supports our belief that red cell deformability as measured by microfiltration is unlikely to represent an important independent risk factor in cerebral thrombosis.

We thank Dr Beynon and Dr Green for permission to study their patients, $\mathrm{Mr} \mathrm{G}$ O'Connell for skilled technical assistance and Miss D Burston for helping us to prepare the manuscript.

\section{References}

${ }^{1}$ Chien Usami S, Dellenbeck RJ, Gregson M. Shear dependent deformation of erythrocytes in rheology of human blood. Am J Physiol 1970;219:136-42.

${ }^{2}$ Reid HL, Dormandy JA, Barnes AJ, Lock PJ, Dormandy TL. Impaired red cell deformability in peripheral vascular disease. Lancet 1976; :666-8.

${ }^{3}$ Boyd MJ, Dodds AJ, Allan J, Bennett CD, Dormandy JA. Decreased erythrocyte deformability after myocardial infarction. Clin Sci 1979;58:12.

${ }^{4}$ Red Cell Deformability. Editorial, Lancet 1978;ii: 1348-9.

${ }^{5}$ Buchan PC. Evaluation and modification of whole blood filtration in the measurement of erythrocyte deformability in pregnancy and the newborn. $\mathrm{Br} J$ Haematol 1980;45:97-105.

${ }^{6}$ Kenny MW, Meakin M, Worthington DS, Stuart J. Erythrocyte deformability in sickle cell crisis. $\mathrm{Br} \mathrm{J}$ Haemutol 1981;49:103-9.

${ }^{7}$ Guerrini M, Rossi C, Acciavatti A et al. Haemorheological aspects of Stroke. 2nd European Conference on Clinical Haemorrheology. 1982 in press.

${ }^{8}$ Dormandy J, Flute P, Ernst E. Reduced red cell filterability following acute myocardial infarction. 2nd European Conference on Clinical Haemorrheology. 1982 in press.

${ }^{9}$ Boisseau MR, Lorient MF, Bricaud H. Red cell deformability and risk factors in 100 patients with cerebro-vascular thrombosis. VIIIth International Congress of Thrombosis und Haemostasis. Thromb Haemost 1979;42:107.

${ }^{10}$ Lorient MF, Boisseau MR, Bricaud H, Manuau JP, Athere C. Reduction de la filtrabilité erythrocytaire 
et accidents vasculaire cerebraux. Sem Hop Paris $1979 ; 55: 27-30$.

${ }^{11}$ Sakuta S, Takamatsu S, Satoh K, Mizuno S, Metoki H. Deformability of erythrocytes in cerebro-vascular disorders. Acta Neurol Scand 1978;60 (suppl 72):614.

${ }^{12}$ Saruta S. Blood filterability in cerebro-vascular disorders with special reference to erythrocyte deformability and APT content Stroke. 1981;126:824-8.

${ }^{13}$ Coccheri S, Dalareti G, Andreoli A, Limoni P, Fagioli L, Poggi M. A study of blood rheology in cerebrovascular patients-Relation to sex, age, clinical features and angiographic findings. 2nd European Conference on Clinical Haemorrheology.
1982, in press.

${ }^{14}$ Reid HL, Barnes AJ, Lock P, Dormandy JA, Dormandy TL. A simple method for measuring erythrocyte deformability. J Clin Pathol 1976;29:855-58.

${ }^{15}$ Schmid-Schonbein H, Volger E. Red cell aggregation and red cell deformability in diabetes. Diabetes 1976; 25 (suppl 2):897-902.

${ }^{16}$ Leonhardt $\mathrm{H}$. Blood viscosity and cardiovascular risk factors. Viscositas 1980;2.2:4-5.

17 Lagrue G, Marcel GA, Grumel JM et al. Red cell filterability and cardio-vascular risk factors. Thromb Haemost 1979;42:106. 